\title{
Growth, Yield Attributes and Yield of Coriander (Coriandrum sativum L.) as Influenced by Weed Management Practices and Nitrogen Levels
}

\author{
J. K. Patil ${ }^{1}$, A. U. Amin ${ }^{2}$, Y. A. Tamboli ${ }^{3 *}$ and U. V. Patel ${ }^{1}$ \\ ${ }^{1}$ Department of Agronomy, Chimanbhai Patel College of Agriculture, S. D. Agricultural \\ University, Sardarkrushinagar, Gujarat-385 506, India \\ ${ }^{2}$ Seed Spices Research Station, Jagudan, S. D. Agricultural University, Sardarkrushinagar, \\ Gujarat-385 506, India \\ ${ }^{3}$ Department of Agronomy, Chaudhary Charan Singh Haryana Agricultural University, Hisar, \\ Haryana-125 004, India \\ *Corresponding author
}

\section{A B S T R A C T}

\begin{tabular}{|l|}
\hline Ke y w or d s \\
Coriander, Growth, \\
$\begin{array}{l}\text { Nitrogen, Weed } \\
\text { control, Yield }\end{array}$ \\
\hline Article Info \\
\hline $\begin{array}{l}\text { Accepted: } \\
\text { 04 March } 2020 \\
\text { Available Online: } \\
\text { 10 April } 2020\end{array}$ \\
\hline
\end{tabular}

An experiment was conducted at Agronomy Instructional Farm, C. P. College of Agriculture, S. D. Agricultural University, Sardarkrushinagar during rabi season of 2016-17 to study the effect of weed and nitrogen management in coriander (Coriandrum sativum L.). The experiment evaluated in Randomized block design with factorial concept and replicated three times. Results show that the significantly lower weed count at $40\left(0.71 \mathrm{~m}^{-2}\right)$ and $60\left(0.71 \mathrm{~m}^{-2}\right)$ DAS, dry weight of weeds $\left(0.00 \mathrm{~kg} \mathrm{ha}^{-1}\right)$ and weed index $(0 \%)$. Whereas, the significantly higher weed control efficiency $(100 \%)$, superior growth parameters, yield attributes and higher seed $\left(1055 \mathrm{~kg} \mathrm{ha}^{-1}\right)$ and straw $\left(1688 \mathrm{~kg} \mathrm{ha}^{-1}\right)$ yield were recorded under weed free $\left(\mathrm{W}_{2}\right)$ and was at par with pre emergence application of pendimethalin $1 \mathrm{~kg} \mathrm{ha}^{-1}+$ interculturing followed by $\mathrm{HW}$ at 30 days after sowing $\left(\mathrm{W}_{6}\right)$. The application of $60 \mathrm{~kg} \mathrm{~N} \mathrm{ha}^{-1}\left(\mathrm{~N}_{3}\right)$ recorded significantly higher values of growth parameters, yield attributes and maximum seed $\left(849 \mathrm{~kg} \mathrm{ha}^{-1}\right)$ and straw $\left(1373 \mathrm{~kg} \mathrm{ha}^{-1}\right.$ ) yield and was at par with $40 \mathrm{~kg} \mathrm{~N} \mathrm{ha}^{-1}\left(\mathrm{~N}_{2}\right)$. Weed count and dry weight of weeds increased significantly with each increase in nitrogen levels from 20 to $60 \mathrm{~kg} \mathrm{~N} / \mathrm{ha}$. But number of weeds per $\mathrm{m}^{2}$ was not influenced by different nitrogen levels. Whereas, the plant population and harvest index was not remarkably influenced by both weed management practices and nitrogen levels. This study revealed that, efficient weed management and remunerative higher yield of coriander can be obtained by adopting integrated weed management approach i.e., application of pendimethalin $1 \mathrm{~kg} \mathrm{ha}^{-1}$ as pre emergence + interculturing followed by hand weeding at 30 DAS along with application of $40 \mathrm{~kg} \mathrm{~N} \mathrm{ha}^{-1}$ under North Gujarat Agro-climatic condition.

\section{Introduction}

India is the world's largest producers, consumers and exporter of seed spices. Among all the states of India, Gujarat and
Rajasthan together contribute more than 80 per cent of the total seed spices production in the country and thus, both the states together are known as "Seed Spices Bowl" of India. Coriander (Coriandrum sativum L.) is an 
annual herb from umbelliferae family with 90 to 120 days growth period. Coriander leaves are being used in cooking, flavouring, beverages etc., and seeds are being used for preparing value added products such as coriander powder, dhana dal, curry powder, oleoresin and essential oil. So, it is known as low volume but high value crop of arid and semi-arid regions. In Gujarat, coriander is cultivated in area of 553 thousand hectares and produced 462 thousand tonnes with averages productivity of $835 \mathrm{~kg} \mathrm{ha}^{-1}$ during 2015 (Anon., 2015). Among different biotic constraint, heavy weed growth is recognized major bottleneck in realizing the full yield potential. Effective weed management is critical to maintaining agricultural productivity (Verma et al, 2015). Since germination and initial growth of coriander are very slow, weed smother this delicate crop at every stage of growth by sharing water, nutrient, space, solar radiation as well as exerting allelopathic effect, resulting in yield loss to the extent of 20-50 per cent (Yadav et $a l .$, 2005).Weed management is important not only to check yield losses but also to increased fertilizer use efficiency.

Among the primary nutrients, nitrogen has a considerable effect, not only on quality of produce but on quantity of produce also. Nitrogen is one of the major elements for growth and development of plant. It is involved in photosynthesis, respiration and protein synthesis. It impart the dark green colour of the leaves, promotes vigorous vegetative growth and more efficient use of available inputs finally leads to higher productivity. At Parbhani (Maharashtra), an experiment was conducted during the rabi season of 2003-2004 to study effect of nitrogen rates $\left(50,75\right.$ and $\left.100 \mathrm{~kg} \mathrm{ha}^{-1}\right)$ and spacing on coriander. Application of nitrogen at a rate of $100 \mathrm{~kg} \mathrm{ha}^{-1}$ resulted in the maximum plant height, number of leaves per plant, number of primary branches per plant, number of secondary branches per plant, eastwest spread of the plant, fresh weight of plant and yield per hectare (Pawar et al., 2007). Therefore, the investigation was conducted with an objective to find out effect of different weed control practices on weed flora, yield attributes and yield of coriander and optimum dose of nitrogen for coriander.

\section{Materials and Methods}

The field experiment was conducted at Agronomy Instructional Farm, C. P. College of Agriculture, Sardarkrushinagar Dantiwada Agricultural University, Sardarkrushinagar (North Gujarat), during rabi 2016-17. Eighteen treatment combinations consisting of six treatments of weed management i.e., weedy check $\left(\mathrm{W}_{1}\right)$, weed free $\left(\mathrm{W}_{2}\right), \mathrm{IC}+\mathrm{HW}$ at 30 and 45 DAS $\left(\mathrm{W}_{3}\right)$, pendimethalin $1 \mathrm{~kg}$ $\mathrm{ha}^{-1}$ as pre emergence $\left(\mathrm{W}_{4}\right)$, pendimethalin 1 $\mathrm{kg} \mathrm{ha}^{-1}$ as pre emergence + imazethapyr $75 \mathrm{~g}$ $\mathrm{ha}^{-1}$ as post emergence at 20-25 DAS $\left(\mathrm{W}_{5}\right)$, pendimethalin $1 \mathrm{~kg} \mathrm{ha}^{-1}$ as pre emergence + interculturing followed by $\mathrm{HW}$ at 30 DAS $\left(\mathrm{W}_{6}\right)$ and three levels of nitrogen i.e., 20, 40 and $60 \mathrm{~kg} \mathrm{ha}^{-1}$ were evaluated in Randomized block design with factorial concept and replicated three times. Geographically, Sardarkrushinagar is situated at $24^{\circ} / 19^{\prime}$ North latitude and $72^{\circ} / 19^{\prime}$ East longitude with an elevation of 154.52 meters above mean sea level. The climate type of this area is subtropical. The soil of experimental field was loamy sand in texture (Sand-81.70\%, Silt$5.62 \%$ and Clay-9.47\%), neutral in $\mathrm{pH}(7.1)$, low in organic carbon $(0.21)$ and available nitrogen $\left(156 \mathrm{~kg} \mathrm{ha}^{-1}\right)$, medium in available phosphorus (41 kg ha-1) and rich in available potassium $\left(296 \mathrm{~kg} \mathrm{ha}^{-1}\right)$. Whereas, EC $(0.17$

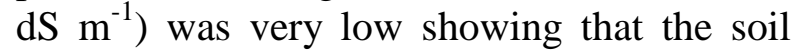
was free from salinity hazard. International Pipette method, Piper, 1966 for physical properties, Schofield method (Jackson, 1973) for EC, Potentiometric method (Jackson, 1973) for soil $\mathrm{pH}$, Walkley and Black's 
method (Jackson, 1973) for organic carbon, Alkaline Potassium Permanganate method (Jackson, 1973) for available nitrogen, Olsen's method (Olsen et al., 1954) for available phosphorus, Flame Photometer method (Jackson, 1973) for available potash.

Half nitrogen was applied as basal dose whereas, remaining half nitrogen applied as top dressing at 30 DAS. A common dose of $10 \mathrm{~kg} \mathrm{P} \mathrm{ha}^{-1}$ was applied through diaammonium phosphate as basal dose. The total weed count at 40, 60 DAS and dry weight of weeds at various growth stage were recorded with the help of a quadrat of $0.5 \mathrm{~m} \times$ $0.5 \mathrm{~m}$ size and per cent reduction in weed dry weight in comparison to unweeded control was as expression as weed control efficiency by Kondap and Upadhyay (1985). To draw a valid conclusion, the weed count data were subjected to square root transformation before statistical analysis. Observations related to growth and yield attributes were recorded at specified growth stages of crop. Harvest index was calculated by using the formula given by Donald and Hamblin (1962) and Weed Index (\%) was calculated by using the formula given Gill and Kumar (1969). Whereas, the statistical analysis of data for each characters studied in the experiment was carried out as per design of the experiment and simple correlation coefficient (' $r$ ') of each character was calculated.

\section{Results and Discussion}

\section{Weed flora}

Weed species found during the course of the investigation have been reported as monocot, dicot and sedge in Table 1 . The major weed populations of monocot weed species viz., Cynodon dactylon L. Pers and dicot weed species i.e., Argemone maxicana L., Amaranthus viridis L., Chenopodium album L., Launaea mudicauli H.K., Asphoidelus tenuifolius L., Melilotus alba Lamk, Tribulus terrestris L., Eurphorbia hirta L., Rumex dentatus L., Leucas aspera Wild were observed during the course of investigation. Cyperus rotundus L. as sedge weed additionally during the period of experiment.

\section{Effect of weed management}

The results in (Table 2) revealed that the total weed count, dry weight of weeds, weed control efficiency, weed index were significantly influenced by various weed management practices. The significantly lower weed count at $40\left(0.71 \mathrm{~m}^{-2}\right)$ and 60 $\left(0.71 \mathrm{~m}^{-2}\right)$ DAS, dry weight of weeds, weed index were recorded under weed free treatment $\left(\mathrm{W}_{2}\right)$ and was at par with pre emergence application of pendimethalin $1 \mathrm{~kg}$ $\mathrm{ha}^{-1}+$ interculturing followed by $\mathrm{HW}$ at 30 days after sowing $\left(\mathrm{W}_{6}\right)$. The probable reason for lower population weeds under $\mathrm{W}_{6}$ treatment might be due to facts that limited weedy condition of field throughout crop life period by hand weeding and interculturing and also effective control of weeds by application of pendimethalin at early growth stages. These findings are in close conformity with the Mehriya et al., (2007) and Patel et al., (2015).

Different weed management practices significantly influenced the plant height at 30, 60 and 90 DAS as well as at harvest, number of branches i.e. primary, secondary and tertiary per plant (Table 3) and revealed that higher plant height at $60(46.7 \mathrm{~cm})$ and 90 $(60.0 \mathrm{~cm})$ DAS as well as at harvest $(66.6$ $\mathrm{cm}$ ), number of branches i.e. primary (5.29), secondary (9.11) and tertiary (13.17) per plant were recorded under weed free treatment $\left(\mathrm{W}_{2}\right)$ and was at par with pre emergence application of pendimethalin $1 \mathrm{~kg} \mathrm{ha}{ }^{-1}+$ interculturing followed by $\mathrm{HW}$ at 30 days after sowing $\left(\mathrm{W}_{6}\right)$. Whereas, the plant population and plant height at 30 DAS was not remarkably 
influenced by weed management practices. Similar kind of reports resulted by Chaudhary et al., (2014), Gohil et al., (2014) and Meena et al., (2015). These improvement in growth parameters of coriander in weed free $\left(\mathrm{W}_{2}\right)$ treatment might be attributed to the reduction in the weed competitiveness by effective removal of weeds throughout crop growth period by physical and integrated weed management practices provide better space and resource to the crop plants i.e., light, water, nutrient, space, etc. which ultimately favoured better environment for growth and development of the crop.

The data presented in Table 4 revealed that number of umbels per plant, umbellates per umbel, seeds per umbellate, seed and straw yield were significantly influenced by various weed management practices. The significantly maximum number of umbels (15.60) per plant, umbellates per umbel (6.01), seeds per umbellate (12.27), seed (1055 kg ha ${ }^{-1}$ ) and straw (1688 kg ha ${ }^{-1}$ ) yield were recorded under weed free treatment $\left(\mathrm{W}_{2}\right)$ and was at par with pre emergence application of pendimethalin $1 \mathrm{~kg} \mathrm{ha}{ }^{-1}+$ interculturing followed by $\mathrm{HW}$ at 30 days after sowing $\left(\mathrm{W}_{6}\right)$.

Whereas, the harvest index was not remarkably influenced by weed management practices. Appreciable reduction in number of weeds at 40 and 60 DAS and dry weight of weeds due to weed free condition $\left(\mathrm{W}_{2}\right)$ and was at par with pre emergence application of pendimethalin $1 \mathrm{~kg} \mathrm{ha}^{-1}+$ interculturing followed by $\mathrm{HW}$ at 30 days after sowing $\left(\mathrm{W}_{6}\right)$ by effective removal of weeds throughout crop growth period by physical and integrated weed management practices provide better space and resource to the crop plants i.e., light, water, nutrient, space, etc. which ultimately favoured better environment for growth and development of the crop might be increased yield and yield attributes.
Per cent increase in seed yield of coriander due to weed free condition $\left(\mathrm{W}_{2}\right)$ were 8.31, 13.56, 19.34, 74.09 and 336 over treatments $\mathrm{W}_{6}, \mathrm{~W}_{3}, \mathrm{~W}_{4}, \mathrm{~W}_{5}$ and $\mathrm{W}_{1}$, respectively. Similarly, seed yield increased in per cent by treatment $\mathrm{W}_{6}$ were $4.84,10.18,60.72$, and 302.47 over treatments $\mathrm{W}_{3}, \mathrm{~W}_{4}, \mathrm{~W}_{5}$ and $\mathrm{W}_{1}$, respectively. Whereas, the lower seed yield of coriander under treatment $\mathrm{W}_{5}$ (Pendimethalin $1 \mathrm{~kg} \mathrm{ha}^{-1}$ as PE + Imazethapyr $75 \mathrm{~g} \mathrm{ha}^{-1}$ as PoE at 20-25 DAS) was observed might be due to phytotoxic effect of post emergence herbicide i.e., imazethapyr on crop and weeds was not controlled effectively at later stage. These finding corroborate the results reported by and Mehariya et al., (2007), Meena and Mehta (2009) Chaudhary et al., (2014), Gohil et al., (2014) and Meena et al., (2015).

\section{Effect of nitrogen levels}

The perusal of data presented in Table 2 revealed that total weed count, dry weight of weeds, weed control efficiency, weed index were significantly influenced by various nitrogen levels. Critical examination of data showed that differences in weed count at 40 and 60 DAS not reach the level of significance (Table 2). However, maximum $(3.20,4.02)$ as well as minimum $(3.04,3.91)$ weed count at 40 and 60 DAS were recorded under the application of 60 and $20 \mathrm{~kg} \mathrm{~N} / \mathrm{ha}$, respectively which indicate that varying levels of nitrogen had not any beneficial or detrimental effect on weed count. As compared to $20 \mathrm{~kg} \mathrm{~N} / \mathrm{ha}$, the percentage of increase in dry weight of weeds under 60 and $40 \mathrm{~kg} \mathrm{~N} / \mathrm{ha}$ were 18.53 and 10.51, respectively. Application of higher dose of nitrogen with split application increased the availability of nutrient for weed growth throughout the crop season which might be resulted in higher dry weight of weeds. These findings are agreements with results reported by Patel et al., (2013), Yadav et al., (2013) and Yadav et al., (2015). 
The data presented in Table 3 revealed that plant height at 30, 60 and 90 DAS as well as at harvest, number of branches i.e. primary, secondary and tertiary per plant were significantly influenced by various nitrogen levels. The application of $60 \mathrm{~kg} \mathrm{~N} \mathrm{ha}{ }^{-1}$ recorded significantly the higher plant height at $60(43.4 \mathrm{~cm})$ and $90(58.0 \mathrm{~cm})$ DAS as well as at harvest $(61.8 \mathrm{~cm})$, number of branches i.e. primary (4.62), secondary (8.29) and tertiary (11.67) per plant and was at par with $40 \mathrm{~kg} \mathrm{~N} \mathrm{ha}{ }^{-1}$. The plant population, plant height at 30 DAS and harvest index was not remarkably influenced by different nitrogen levels. Similar kind of reports resulted by Naghera et al., (2000), Datta et al., (2008), Chaudhary et al., (2014) and Lokhande et al., (2015). Nitrogen, being a major structure constituents of cell, helps in stimulating the cell division and cell elongation, which increased in plant height. Better effect of higher levels of nitrogen might be attributed to rapid expansion of dark green foliage, which could intercept and utilize more light energy in the production of food through the process of photosynthesis. Thus, increased production of food help in increased in plant height and number of primary, secondary as well as tertiary branches per plant.

Different nitrogen levels significantly influenced then umber of umbels per plant, umbellates per umbel, seeds per umbellate, seed and straw yield (Table 4) and revealed that higher number of umbels (14.14) per plant, umbellates per umbel (5.45), seeds per umbellate (11.03), seed (849 $\left.\mathrm{kg} \mathrm{ha}^{-1}\right)$ and straw (1373 kg ha-1) yield. The higher vegetative growth and yield attributes was reported by application of $60 \mathrm{~kg} \mathrm{~N}^{-1}$. This might be due to increased supply of nitrogen, being a major structural constituent of cell, help in stimulating the cell division and cell elongation and the process of tissue differentiation from somatic to reproductive meristematic activity and development of floral primordial might have increased in vegetative growth and more number of umbels per plant. Similarly, adequate supply of nitrogen sustains the uptake of nitrogen up to later crop growth stages.

Table.1 Weed flora observed in experiment

\begin{tabular}{|c|c|c|c|}
\hline Sr. No. & Local name & Scientific Name & Family \\
\hline (A) & \multicolumn{3}{|c|}{ Monocot weed } \\
\hline 1. & Dharo & Cynodon dactylon Pers. & Poaceae \\
\hline (B) & \multicolumn{3}{|l|}{ Dicot weeds } \\
\hline 1. & Darudi & Argemone maxicana $\mathrm{L}$. & Papavaraceae \\
\hline 2. & Tandalja & Amaranthus viridis L. & Amaranthaceae \\
\hline 3. & Chill & Chenopodium album L. & Chinopodaceae \\
\hline 4. & Bhoi pathri & Launaea mudicauli H.K & Compositeae \\
\hline 5. & Dungaro & Asphoidelus tenuifolius L. & Liliaceae \\
\hline 6. & Methyu & Melilotus alba Lamk L. & Leguminoseae \\
\hline 7. & Gokhru & Tribulus terrestris L. & Zygophyllaceae \\
\hline 8. & Dudheli & Eurphorbia hirta L. & Euphorbiaceae \\
\hline 9. & Jangli palk & Rumex dentatus L. & Cyperaceae \\
\hline 10. & Kubi & Leucas aspera Wild. & Lamiaceae \\
\hline (C) & \multicolumn{3}{|l|}{ Sedge weed } \\
\hline 1. & Chidho & Cyperus rotundus L. & Cyperaceae \\
\hline
\end{tabular}


Table.2 Total weed count, dry weight of weeds, weed control efficiency and weed index as influenced by different weed management practices and nitrogen levels

\begin{tabular}{|c|c|c|c|c|c|}
\hline \multirow[b]{2}{*}{ Weed management $(\mathrm{W})$} & \multicolumn{2}{|c|}{$\begin{array}{c}\text { Total weed count } \\
\text { (Number of weeds } \mathbf{m}^{-2} \text { ) }\end{array}$} & \multirow{2}{*}{$\begin{array}{l}\text { Dry weight } \\
\text { of weeds } \\
\left(\mathrm{kg} \mathrm{ha}^{-1}\right)\end{array}$} & \multirow{2}{*}{$\begin{array}{c}\text { Weed } \\
\text { control } \\
\text { efficiency } \\
(\%)\end{array}$} & \multirow{2}{*}{$\begin{array}{c}\text { Weed } \\
\text { index } \\
(\%)\end{array}$} \\
\hline & 40 DAS & 60 DAS & & & \\
\hline $\mathrm{W}_{1}$ : Weedy check & $\begin{array}{c}6.21 \\
(38.11)\end{array}$ & $\begin{array}{c}7.05 \\
(49.30)\end{array}$ & 3366 & - & 77 \\
\hline $\mathrm{W}_{2}:$ Weed free & $\begin{array}{c}0.71 \\
(0.00)\end{array}$ & $\begin{array}{c}0.71 \\
(0.00)\end{array}$ & 0.00 & 100 & - \\
\hline $\mathrm{W}_{3}: \mathrm{IC}+\mathrm{HW}$ at 30 and 45 DAS & $\begin{array}{c}2.04 \\
(3.68)\end{array}$ & $\begin{array}{c}2.89 \\
(7.88)\end{array}$ & 646 & 80.83 & 12 \\
\hline $\mathrm{W}_{4}$ : Pendimethalin $1 \mathrm{~kg} \mathrm{ha}^{-1}$ as PE & $\begin{array}{c}2.47 \\
(5.63)\end{array}$ & $\begin{array}{c}3.63 \\
(12.70)\end{array}$ & 1334 & 60.41 & 16 \\
\hline $\begin{array}{l}\mathrm{W}_{5}: \text { Pendimethalin } 1 \mathrm{~kg} \mathrm{ha}^{-1} \text { as PE + Imazethapyr } 75 \mathrm{~g} \\
\text { ha }^{-1} \text { as PoE at 20-25 DAS }\end{array}$ & $\begin{array}{c}2.64 \\
(6.47)\end{array}$ & $\begin{array}{c}4.05 \\
(15.93)\end{array}$ & 1818 & 46.05 & 42 \\
\hline $\begin{array}{l}\mathrm{W}_{6} \text { : Pendimethalin } 1 \mathrm{~kg} \mathrm{ha}^{-1} \text { as PE + IC followed by HW } \\
\text { at } 30 \text { DAS }\end{array}$ & $\begin{array}{c}1.69 \\
(2.38)\end{array}$ & $\begin{array}{c}2.65 \\
(6.57)\end{array}$ & 337 & 90 & 7 \\
\hline S.Em. \pm & 0.08 & 0.11 & 45 & - & - \\
\hline C.D. at 5\% & 0.22 & 0.32 & 129 & - & - \\
\hline \multicolumn{6}{|l|}{ Levels of nitrogen $(\mathrm{N})$} \\
\hline $\mathrm{N}_{1}: 20 \mathrm{~kg} \mathrm{ha}^{-1}$ & $\begin{array}{c}3.04 \\
(8.76)\end{array}$ & $\begin{array}{c}3.91 \\
(14.83)\end{array}$ & 1197 & - & - \\
\hline $\mathrm{N}_{2}: 40 \mathrm{~kg} \mathrm{ha}^{-1}$ & $\begin{array}{c}3.17 \\
(9.59)\end{array}$ & $\begin{array}{c}4.01 \\
(15.62)\end{array}$ & 1240 & - & - \\
\hline$N_{3}: 60 \mathrm{~kg} \mathrm{ha}^{-1}$ & $\begin{array}{c}3.20 \\
(9.78)\end{array}$ & $\begin{array}{c}4.02 \\
(15.74)\end{array}$ & 1315 & - & - \\
\hline S.Em. \pm & 0.06 & 0.08 & 32 & - & - \\
\hline C.D. at $5 \%$ & NS & NS & 91 & - & - \\
\hline C.V. \% & 8.92 & 9.78 & 11.0 & - & - \\
\hline Interaction effect $(\mathbf{W} \times \mathbf{N})$ & NS & NS & NS & - & \\
\hline
\end{tabular}

Note: Retransform values of square root transformation $(\sqrt{\mathrm{x}+0.5})$ before analysis are writtenin parenthesis.

IC =Interculturing, $\mathrm{HW}=$ hand weeding, $\mathrm{PE}=$ pre emergence, $\mathrm{PoE}=$ Post emergence 
Table.3 Growth parameter of coriander as influenced by different weed management practices and nitrogen levels

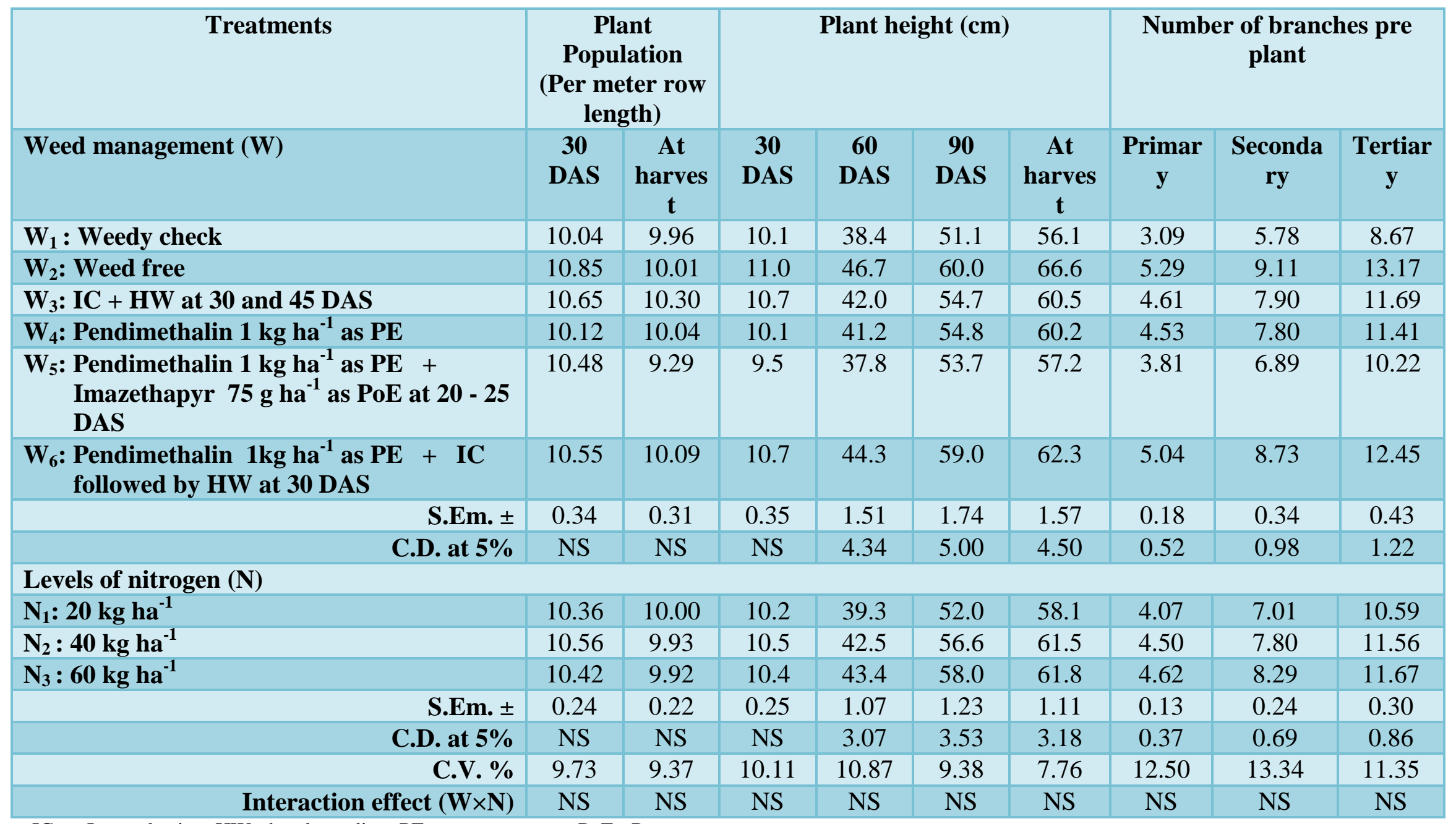

IC =Interculturing, $\mathrm{HW}=$ hand weeding, $\mathrm{PE}=$ pre emergence, $\mathrm{PoE}=$ Post emergence 
Table.4 Yield parameters and yield of coriander as influenced by different weed management practices and nitrogen levels

\begin{tabular}{|c|c|c|c|c|c|c|}
\hline Treatments & \multirow{2}{*}{$\begin{array}{c}\text { Umbels } \\
\text { per plant }\end{array}$} & \multirow{2}{*}{$\begin{array}{l}\text { Umbellat } \\
\text { es per } \\
\text { umbels }\end{array}$} & \multirow{2}{*}{$\begin{array}{c}\text { Seeds per } \\
\text { umbellat } \\
\text { e }\end{array}$} & \multirow{2}{*}{$\begin{array}{c}\text { Seed } \\
\text { yield (kg } \\
\left.\text { ha }^{-1}\right)\end{array}$} & \multirow{2}{*}{$\begin{array}{c}\text { Straw } \\
\text { yield (kg } \\
\left.\text { ha }^{-1}\right)\end{array}$} & \multirow{2}{*}{$\begin{array}{c}\text { Harvest } \\
\text { index } \\
(\%)\end{array}$} \\
\hline Weed management $(\mathrm{W})$ & & & & & & \\
\hline$W_{1}$ : Weedy check & 9.66 & 4.26 & 7.34 & 242 & 493 & 32.31 \\
\hline $\mathrm{W}_{3}: \mathrm{IC}+\mathrm{HW}$ at 30 and 45 DAS & 13.92 & 5.06 & 10.97 & 929 & 1481 & 38.49 \\
\hline $\mathrm{W}_{4}$ : Pendimethalin $1 \mathrm{~kg} \mathrm{ha}^{-1}$ as PE & 13.97 & 5.25 & 10.57 & 884 & 1470 & 37.32 \\
\hline $\begin{array}{l}\mathrm{W}_{5}: \text { Pendimethalin } 1 \mathrm{~kg} \mathrm{ha}^{-1} \text { as PE + Imazethapyr } 75 \\
\text { g ha }^{-1} \text { as PoE at 20-25 DAS }\end{array}$ & 12.39 & 4.28 & 8.59 & 606 & 1027 & 37.02 \\
\hline S.Em. \pm & 0.52 & 0.23 & 0.37 & 32 & 68.02 & 1.71 \\
\hline C.D. at $5 \%$ & 1.49 & 0.66 & 1.06 & 93 & 195.49 & NS \\
\hline \multicolumn{7}{|l|}{ Levels of nitrogen $(\mathrm{N})$} \\
\hline $\mathrm{N}_{1}: 20 \mathrm{~kg} \mathrm{ha}^{-1}$ & 12.02 & 4.59 & 9.11 & 711 & 1196 & 37.64 \\
\hline C.V. \% & 11.63 & 13.70 & 10.83 & 12.41 & 15.64 & 13.64 \\
\hline Interaction effect $(\mathrm{W} \times \mathrm{N})$ & NS & NS & NS & NS & NS & NS \\
\hline
\end{tabular}

IC =Interculturing, $\mathrm{HW}=$ hand weeding, $\mathrm{PE}=$ pre emergence, $\mathrm{PoE}=$ Post emergence 
Table.5 Correlation coefficient (r) between seed yield and growth as well as yield attributing characters

\begin{tabular}{|c|c|c|}
\hline Sr. No. & Characters & Correlation coefficient (r) \\
\hline 1 & Plant height at harvest & $0.663^{* *}$ \\
\hline 2 & $\begin{array}{l}\text { Number of primary branches } \\
\text { per plant }\end{array}$ & $0.898^{* *}$ \\
\hline 3 & $\begin{array}{l}\text { Number of secondary } \\
\text { branches per plant }\end{array}$ & $0.819^{* *}$ \\
\hline 4 & $\begin{array}{l}\text { Number of tertiary branches } \\
\text { per plant }\end{array}$ & $0.918^{* *}$ \\
\hline 5 & Number of umbels per plant & $0.891^{* *}$ \\
\hline 6 & $\begin{array}{l}\text { Number of umbellates per } \\
\text { umbel }\end{array}$ & $0.740^{* *}$ \\
\hline 7 & $\begin{array}{l}\text { Number of seeds per } \\
\text { umbellate }\end{array}$ & $0.881^{* *}$ \\
\hline 8 & Weed count at 60 DAS & $-0.897^{* *}$ \\
\hline 9 & $\begin{array}{l}\text { Dry weight of weeds (kg ha- } \\
1 \text { ) }\end{array}$ & $-0.936^{* *}$ \\
\hline & $\begin{array}{ll}= & \text { Significant } \\
= & \text { Significant }\end{array}$ & $\begin{array}{l}5 \text { per cent level } \\
1 \text { per cent level }\end{array}$ \\
\hline
\end{tabular}

Moreover, addition of optimum dose of nitrogen might have helped to better translocation of photosyanthates from leaves to sink site i.e., umbellates and seeds, which finally led to more seed setting.

In general, seed and stover yield of coriander increased with increase in levels of nitrogen from 20 to $60 \mathrm{~kg} \mathrm{ha}^{-1}$ but significant increase was observed up to $40 \mathrm{~kg} \mathrm{~N} \mathrm{ha}{ }^{-1}$. As compared to $20 \mathrm{~kg} \mathrm{~N} \mathrm{ha}^{-1}$, the respective rise in seed and stover yield under application of nitrogen 40 and $60 \mathrm{~kg} \mathrm{ha}^{-1}$ were 10.54 and 19.40 as well as 12.20 and 14.79 per cent, respectively. Increasing trends as observed in seed yield was evidently due to overall improvement in vegetative stage in the terms of plant height and number of branches per plant at higher levels of nitrogen, which positively influenced on yield contributing characters. Better effect of higher levels of nitrogen might be attributed to rapid expansion of dark green foliage, which could intercept and utilize more light energy in the production of food through the process of photosynthesis. Thus, increased production of food help in increased in growth attributes which might be responsible for higher straw yield. Similar findings are also reported by Thakaral et al., (1992), Sivakumaran et al., (1996), Naghera et al., (2000), Patel et al., (2004), Patel (2006), Pawar et al., (2007), Datta et al., (2008), Patel et al., (2013), Chaudhary et al., (2014) and Lokhande et al., (2015).

\section{Interaction effect}

The interaction effect between weed management practices and nitrogen levels was not significant.

\section{Correlation coefficient}

The correlation coefficient (' $r$ ') between seed yield and growth as well as yield attributing character was worked out as per Table 5. It was noticed that growth parameters viz., plant 
height and number of primary, secondary and tertiary branches per plant and yield attributes i.e., number of umbels per plant, umbellates per umbel and seeds per umbellate showed positive significant correlation with seed yield, while weed studies i.e., total weed count at 60 DAS and dry weight of weeds showed negative significant correlation with seed yield. Similar finding have been also reported by Bhati et al., (1989).

On the basis of experiment, it is concluded that efficient weed management and remunerative higher yield of coriander can be obtained by adopting integrated weed management approach i.e., application of pendimethalin $1 \mathrm{~kg} \mathrm{ha}^{-1}$ as pre emergence + interculturing followed by hand weeding at 30 DAS along with application of $40 \mathrm{~kg} \mathrm{~N}^{-1}$ under North Gujarat Agro-climatic condition.

\section{References}

Anonymous, 2015. State of Indian Agriculture 2014-15. Department of Agriculture and Co-operation, Ministry of Agriculture, Government of India, New Delhi. pp. 202-205.

Chaudhary, I., Yadav, S. S., Yadav, L. R. Sharma, O. P. and Yadav, B. L. 2014. Effect of weed and nitrogen management on coriander (Coriandrum sativum L.) yield and economics. Journal of Spices and Aromatic Crops. 23(1): 38-44.

Datta, S., Alam, K. and Chatterjee, R. 2008. Effect of different levels of nitrogen and leaf cutting on growth, leaf and seed yield of coriander (Coriandrum sativum L.). Indian Journal of Horticulture. 65(2):201-203.

Donald, C. N. and Hamblin, J. 1976. The biological yield and harvest index of cereals as agronomic and plant breeding criteria. Advance Agronomy.28: 361-405.

Fagaria, V. D., Gupta, K. C. and Saxena, R. 2014. Integrated weed management in fenugreek (Trigonella foenum-graecum L.) in semi arid regions of Rajasthan.
International Journal of Agricultural Science. 10(1): 302-304.

Gill, G. S. and Kumar, V. 1969. Weed index a new method for reporting weed control traits. Indian Journal of Agronomy. 6(2): 96-98.

Gohil, B. S, Mathukia, R. K., Dobaria, V. K. and Chhodavodia, S. K. 2014. Weed management and dynamics of weed seed bank in fennel (Foeniculum valgare Mill.). Indian Journal of Agricultural Science. 46(4): 399-401.

Jackson, M. L. 1973. Soil chemical analysis. Prentice Hall of India Pvt. Ltd., New Delhi.

Kondap, S. M. and Upadhyay, U. C. 1985. A practical manual on weed control. Oxford and IBH Publishing Co., New Delhi. pp.55.

Lokhande, S. N., Jogdande, N. D and Thakare, S. S. 2015. Effect of varying levels of nitrogen and phosphorus on growth and seed yield of coriander (Coriandrum sativum L.). Plant Achives. 15(1): 57- 59.

Meena, R. L., Meena, S. S., Mehta, R. S and Meena, R. D. 2015. Weed management in ajwain (Trachyspermum ammi L.). Journal of Spices and Aromatic Crop. 24(2): 124-128.

Meena, S. S. and Mehta, R. S. 2009. Integrated weed management in coriander (Coriandrum sativum L.). Indian Journal of Agricultural Science. 79(10): 824-826.

Mehriya, M. L., Yadav, R. S., Jangir, R. P. and Poonia, B. L. 2007. Nutrient utilization by cumin (Cuminum cyminum L.) and weed influenced by different weed control methods. Indian Journal of Agronomy. 52(2): 176-179.

Naghera, R. P., Sukhadia, N. M. and Ramani, B. B. 2000. Effect of sowing dates and levels of nitrogen and phosphorus on coriander (Coriandrum sativum L.). Gujarat Agriculture Research Journal. 26(1): 52-54.

Olsen, S. R., Cole, V. C., Watanable, P. S. and Dean, L. A. 1954. Estimation of available phosphorus in soil by extraction with sodium bicarbonate. U.S.D.A., Circ. No. 
939.

Patel, C. B., Amin, A. U. and Patel, A. L. 2013. Effect of varying levels of nitrogen and sulphur on growth and yield of coriander (Coriandrum sativum L.). The bioscan. 8(4): 1285-1289.

Patel, K. J. 2006. Response of ajwain (Trachyspermum ammi L.) to spacing under varying levels of nitrogen and phosphorus. M.Sc. (Agri.) Thesis, submitted to Sardarkrushinagar Dantiwada Agricultural University, Sardarkrushinagar.

Patel, R. H., Shroff, J., Usavadia, V. P. and Shah, S. N. 2004. Influence of nitrogen and weed management practices on weeds and coriander (Coriandrum sativum L.). Indian Journal of Weed Science. 36 (1\&2): 86-88.

Patel, S. M., Amin, A. U., Patel, S. P. and Patel, J. B. 2015. Weed management in cumin (Cuminum cyminum L.). In: $25^{\text {th }}$ AsianPacific Weed Science Society Conference on "Weed Science for Sustainable Agriculture, Environment and Biodiversity”. Hyderabad, 13-16 October, 2015. pp. 372.

Pawar, P. M., Naik, D. M., Damodhar,V. P., Shinde, V. N. and Bhalerao, R.V. 2007. Influence of graded levels of spacing and nitrogen on growth and yield of coriander (Coriandrum sativum L.). Asian Journal of Horticulture. 2(1): 58-60.

Piper, C. S. 1966. Soil and plant analysis. The University of Adelaide, Academic Press, New York., Australia.
Sivakumaran, S., Hunsigi, G., Basavaraju, H. K. and Sridhara, S. 1996. Study on nutrient uptake, seed and oil yield of coriander (Coriandrum sativum L.) as influence by N, P and S. Indian Agriculturist. 40(2): 89-92.

Thakaral, K. K., Singh, G. R., Pandey, U. S. and Shirivastava, V. K. 1992. Effect of nitrogen levels and cutting production of green leaves and seed yield of coriander (Coriandrum sativum L.). Haryana Journal of Agriculture Research. 22: 3539.

Verma, S. K., Singh, S. B., Meena, R. N., Prasad, S. K., Meena, R. S. and Gaurav 2015. A review of weed management in India the need of new directions for sustainable agriculture. The Bioscan, 10(1): 253-263.

Yadav, S. S., Chaudhary, I., Yadav, L. R. and Keshwa, G. L. 2013. Growth and yield of coriander (Coriandrum sativum L.) as influenced by weed management and nitrogen levels. Indian Journal of Agronomy. 58(4): 597-602.

Yadav, S. S., Chodhary, I., Yadav, L. R. and Sharma, O. P. 2015. Weed management in coriander (Coriandrum sativum L.) at varying levels of nitrogen. Journal of Spices and Aromatic Crops. 25(1): 18-25.

Yadav, S. S., Sharma, O. P. and Yadav, R. D. 2005. Comparatively efficacy of herbicide and manual weed control in cumin (Cuminum cyminum L.) at different levels of nitrogen. Indian Journal of Agronomy. 50(1): 77-79.

\section{How to cite this article:}

Patil, J. K., A. U. Amin, Y. A. Tamboli and Patel, U. V. 2020. Growth, Yield Attributes and Yield of Coriander (Coriandrum sativum L.) as Influenced by Weed Management Practices and Nitrogen Levels. Int.J.Curr.Microbiol.App.Sci. 9(04): 328-338.

doi: https://doi.org/10.20546/ijcmas.2020.904.039 